\title{
Development and Physico-Chemical Evaluation of Low Fat Chicken Nuggets using Extenders
}

\author{
Aditiya Kumar Singh ${ }^{1 *}$, Chitra Sonkar ${ }^{2}$ and Dorcus Messih ${ }^{3}$ \\ ${ }^{1}$ Department of Food Process Engineering, SRM University, India \\ ${ }^{2}$ Vaugh School of Agricultural Engineering and Technology, India \\ ${ }^{3}$ Sam Higginbottom Institute of Agriculture, Technology and Sciences, Allahabad, UP, India
}

\begin{abstract}
The study was aimed at evaluating the effect of soya chunk (SC) and chick pea flour (CF) on the quality of low fat chicken nuggets. SC and CF were incorporated in minched chicken meat at 5\% (T1), 10\% (T2) and 15\% (T3) level and compared with the control (T0) prepared without the incorporation of CF and SC the quality parameters studied included physico - chemical indices including moisture (\%), protein (\%), fat (\%) and sensor attributes. Moisture (\%), protein (\%), fat (\%), carbohydrates $(\%)$ and ash (\%) content showed non-significant difference when compared with control. Among sensory attributes, texture and overall acceptability showed significant difference with higher scores at $20 \%$ level of incorporation. From the study it was concluded that overall quality of nuggets prepared with incorporation of $\mathrm{CF}$ and SC was better than other treatments.
\end{abstract}

Keywords: Chicken nuggets; CF; Physico-chemically; SC; Sensory evaluation

\section{Introduction}

The main composition of nugget is meat, usually from chicken, fish or combination with vegetable protein and gum. The composition of all batter is flour. In India, chicken nuggets are an important food served at almost all fast food restaurant chains. Proximate composition and physicochemical characteristics of chicken nuggets are the most significant factors for consumer acceptability. According to the Indian Food Regulation (Food Act 1983 and Regulations 1985) restructured meat products must contain not less than $60 \%$ meat in any formulation. USDA (1991) suggested the coat of the nugget should be less than the weight of product. At present, soybean proteins are the predominant additives for use as fillers, binders, and extenders in meat systems [1,2]. In contrast, nonmeat protein additives derived from cowpeas and peanuts are less common. Partial replacement of meat with cowpea and peanut proteins has been reported [3-8]. Loss of emulsion properties of fermented cowpea flour as a result of heat treatment during flour preparation [9] precludes its uses in emulsion type extended meat products. This present work is undertaken to develop low fat chicken nuggets.

\section{Materials and Methods}

The experimental studies were carried out in the Department of Food Process Engineering, Vaugh School of Agricultural Engineering, Sam Higginbottom Institute of Agriculture, Technology and Sciences, Allahabad.

\section{Preparation of chicken nuggets}

The chicken nugget was prepared using the following flow sheet to fulfill various objectives. Four samples duplicate in three batches are prepared using different extenders i.e. chickpea flour and soya chunk for comparison of the above two sample used, and their proximal, physiochemical analysis was done (Figure 1).

Chemicals: Petroleum ether, hydrochloric acid, methyl red indicator, Copper sulphate, Sodium hydroxide, potassium sulphate, $\mathrm{HNO}_{3}$.

Treatment: T0- Low fat chicken nuggets was prepared using $100 \%$ chicken meat, $0 \%$ soya chunk and $0 \%$ chickpea flour.
T1- Low fat chicken nuggets was prepared using $90 \%$ chicken meat, $5 \%$ soya chunk and $5 \%$ chickpea flour

T2- Low fat chicken nuggets was prepared using $80 \%$ chicken meat, $10 \%$ soya chunk and $10 \%$ chickpea flour

T3- Low fat chicken nuggets was prepared using $70 \%$ chicken meat, $15 \%$ soya chunk and $15 \%$ chickpea flour.

\section{Physico-chemical analysis}

Determination of moisture: Determination of moisture was done by the conventional method known as hot air drying method. Each food has its own characteristics water content.

\section{Calculation:}

Moisture (\%) = W1-W2×100 / W1

Where, $\mathrm{W} 1$ = weight $(\mathrm{g})$ of sample before drying

$\mathrm{W} 2=$ weight $(\mathrm{g})$ of sample after drying.

Determination of ash: Determination of ash by muffle furnace proposed by Ranganna, 1986. Percent ash was calculated using the formula:

\section{Calculation:}

\section{Ash $\%=\underline{\text { Wt of dish and ash }-\mathrm{Wt} \text { of dish } \times 100}$}

\section{Wt of sample}

Determination of fat: The solvent extraction methods used for fat analysis are Soxhlet method.

*Corresponding author: Aditiya Kumar Singh, Department of Food Process Engineering, SRM University, India, Tel: 91532 2684281; E-mail: adi7221@gmail.com

Received July 21, 2014; Accepted August 22, 2014; Published August 29, 2014

Citation: Singh AK, Sonkar C, Messih D (2014) Development and PhysicoChemical Evaluation of Low Fat Chicken Nuggets using Extenders. J Food Process Technol 5: 369. doi:10.4172/2157-7110.1000369

Copyright: (๑) 2014 Singh AK, et al. This is an open-access article distributed unde the terms of the Creative Commons Attribution License, which permits unrestricted use, distribution, and reproduction in any medium, provided the original author and source are credited. 


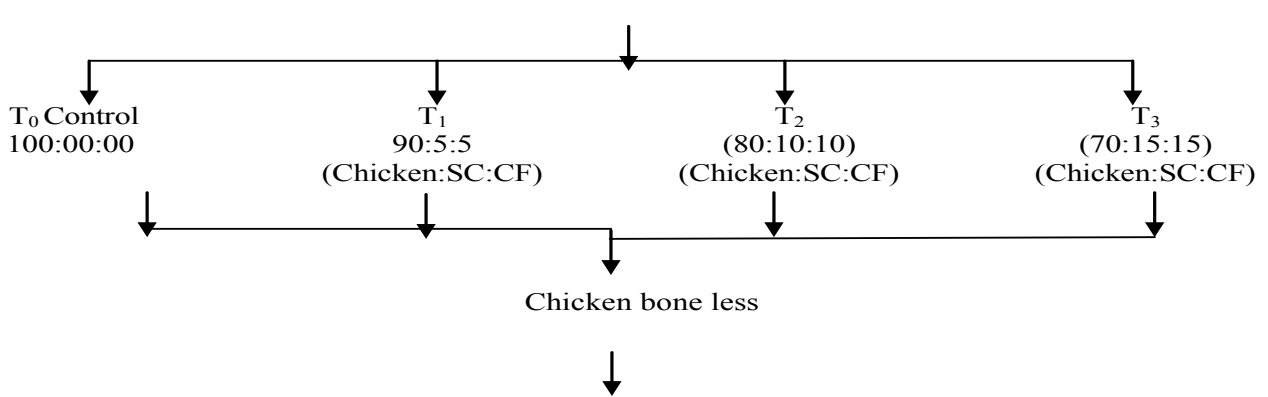

Minced the chicken

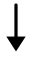

Addition of extender

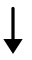

Mould mixture in a tray

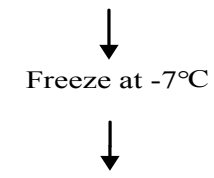

Cut in to desire size

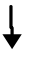

Pre-dusting is done

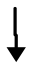

Dip the pieces in to batter

$\downarrow$

Breading is done

$\downarrow$

Heat treatment (at $175^{\circ} \mathrm{C}$ for short time)

$\downarrow$

Cooling

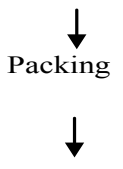

Stored at $-18^{\circ} \mathrm{C}$

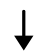

Deep fry until golden brown

$\downarrow$

Physiochemical analysis

Figure 1: Flow sheet of chicken nugget preparation. 
Calculation: The total fat content $(\mathrm{w})$ in $\mathrm{g} / 100 \mathrm{~g}$ (corresponds to \%) of the sample is calculated using the following formula:

$\mathrm{W}=\mathrm{M}_{2}-\mathrm{M}_{1}^{*} 100 / \mathrm{M}_{0}$

$\mathrm{M}_{1}$ : Mass of the empty extraction beaker with boiling stones in $\mathrm{g}$

$\mathrm{M}_{2}$ : Mass of the extraction beaker with fat after drying in $\mathrm{g}$

$\mathrm{M}_{0}$ : Weight at the start of the analysis in $\mathrm{g}$

The result is expressed to two decimal places.

Determination of protein: The protein content was determined by The Kjeldahl, The methods are from the Official Methods of Analysis of AOAC International, and are used commonly in research laboratories working on proteins.

Calculation: $\% \mathrm{~N}=1.4007{ }^{*} \mathrm{c}(\mathrm{V}-\mathrm{Vb}) /$ Sample weight $(\mathrm{g})$

c: Concentration of the standard-acid solution: Hydrochloric acid $0.1 \mathrm{~N}$ or $\mathrm{c}=0.1 \mathrm{~mol} / \mathrm{l}$
Alternative: sulfuric acid $0.1 \mathrm{~N}$ or $\mathrm{c}=0.05 \mathrm{~mol} / \mathrm{l}$
$\mathrm{V}$ : Consumption of the standard acid in ml (Sample)
Vb: Consumption of the standard acid in ml (Blank Sample)
$\%$ raw protein $=\% \mathrm{~N}^{*} 6.25$

\section{Estimation of total carbohydrate}

The carbohydrate content was calculated by using formula

Carbohydrates $($ percent $)=100-($ moisture + ash + protein + fat $)$

Yeast and mold count (C.F.U.) /g. or / ml.: Yeast and mold count was measured by the colony count unit

\section{Sensory analysis}

Sensory attributes including color, aroma, and taste and overall accept ability was determine by hedonic rating scale as recommended by Ranganna. Hedonic rating scale will be used for evaluation of sensory characteristics.

\section{Results and Discussion}

Nutritional adequacy is one of the key determinants of the quality of human life everywhere. In India dietaries which are mostly non-vegetarian, liberal amount of soya chunk, chickpea flour and chicken meat have been advocated as important source of several nutrients especially low fat and high protein. It is also well recognized that there are some meat product which are easily available and are relatively cheap. Recent development in the non-vegetarian production technology has significantly contributed in the increase of these food items. However efforts to prevent the losses between production and consumption are in progress.

\section{Physio-chemical analysis}

Moisture content: The proximate composition for chicken nuggets were significantly different $(\mathrm{P}<0.05)$. Sample $\mathrm{T}_{3}$ has the lowest moisture content that is $40.92 \%$, while sample $\mathrm{T}_{0}$ has the highest moisture content that is $47.33 \%$ (Figure 2 ). One important property of a nonmeat protein intended as a meat additive is the ability to bind water $[10,11]$. It has been observed that the initial value of all the samples are $52.130 \%, 50.083 \%, 47.987 \%$, and $45.27 \%\left(\mathrm{~T}_{0}, \mathrm{~T}_{1}, \mathrm{~T}_{2}\right.$, and $\left.\mathrm{T}_{3}\right)$ and after the storage period of 45 days the moisture content observed are $47.33 \%, 45.647 \%, 43.613 \%$, and $40.920 \%\left(\mathrm{~T}_{0}, \mathrm{~T}_{1}, \mathrm{~T}_{2}\right.$, and $\left.\mathrm{T}_{3}\right)$ this

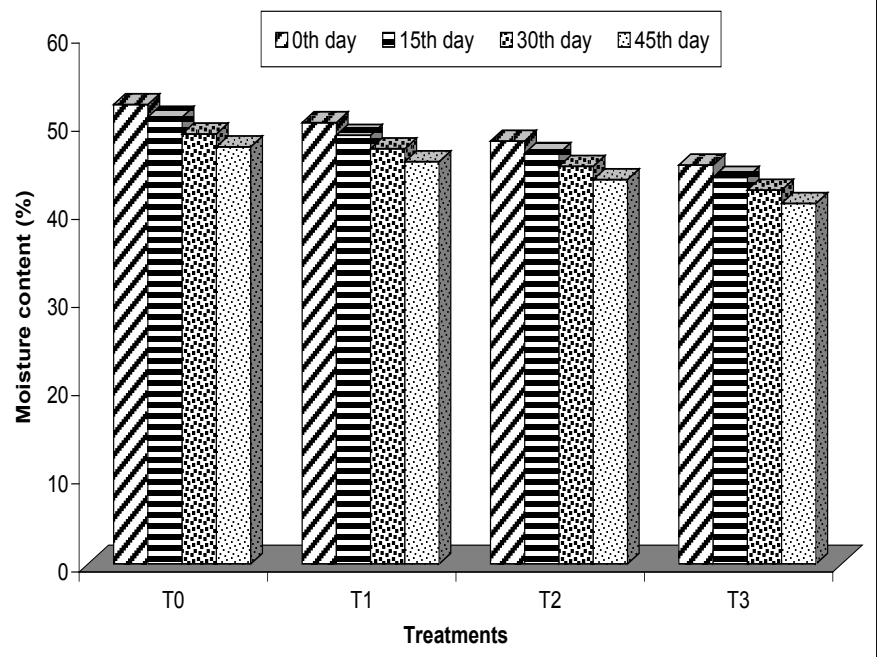

Figure 2: Moisture content (\%) of low fat chicken nuggets packed in HDPE during 45 days of refrigerated storage.

change in moisture content because of partial permeability character of HDPE due to which loss of moisture takes place These findings are in conformity with the results of Prinyawiwatkul et al. [12]

Ash content: The ash content in chicken nuggets varied from 2.22-2.42\%. According to Field [13], the ash content for mechanically deboned chicken meat is higher compared to traditional deboned chicken meat (chicken meat deboned by hand). This is because during the process of mechanical deboning, the bones of the meat were crushed and mixed into the mince causing higher ash content. It has been observed that the initial value of ash in all the samples are $2.403 \%$, $2.460 \%, 2.547 \%$ and $2.623 \%\left(\mathrm{~T}_{0}, \mathrm{~T}_{1}, \mathrm{~T}_{2}\right.$ and $\left.\mathrm{T}_{3}\right)$ and after the storage period of 45 days the ash content observed are $2.223 \%, 2.290 \%, 2.373 \%$ and $2.427 \%\left(\mathrm{~T}_{0}, \mathrm{~T}_{1}, \mathrm{~T}_{2}\right.$ and $\left.\mathrm{T}_{3}\right)$ (Figure 3 ). This variation in ash content is due to mixing of extenders These findings are in conformity with the results of Scheffe et al. [14].

Fat content: Fat content was highest in $\mathrm{T}_{0}(22.05 \%)$ and lowest in $\mathrm{T}_{3}$ (15.24). Reduction in fat can significantly affect the acceptability of a product and increase the toughness of meat product. These findings are in conformity with the results of Giese [15]. It has been observed that the initial value of fat in all the samples are $18.133 \%, 16.32 \%, 14.507 \%$ and $12.673 \%\left(\mathrm{~T}_{0}, \mathrm{~T}_{1}, \mathrm{~T}_{2}\right.$ and $\left.\mathrm{T}_{3}\right)$ and after the storage period of 45 days the fat content observed are $22.053 \%, 19.913 \%, 17.923 \%$ and $15.243 \%$ $\left(\mathrm{T}_{0}, \mathrm{~T}_{1}, \mathrm{~T}_{2}\right.$ and $\mathrm{T}_{3}$ ) (Figure 4). This variation is due to incorporation of extenders which may have been due to differences in fat binding properties of flour proteins noted by Prinyawiwatkul et al. [8,9].

Protein content: It has been observed that the initial value of protein in all the samples are $12.507 \%, 14.933 \%, 17.327 \%$, and $19.740 \%$ $\left(\mathrm{T}_{0}, \mathrm{~T}_{1}, \mathrm{~T}_{2}\right.$ and $\left.\mathrm{T}_{3}\right)$ and after the storage period of 45 days the protein content observed are $12.577 \%, 15.213 \%, 17.627 \%$, and $20.240 \%\left(\mathrm{~T}_{0}\right.$, $\mathrm{T}_{1}, \mathrm{~T}_{2}$ and $\mathrm{T}_{3}$ ) (Figure 5). The difference in protein content depends on the raw material that is used in the manufacturing of chicken nuggets. In short, protein content in chicken nuggets comes mainly from raw material so a higher amount of raw material used in the formulation was result in higher protein content. These findings are in conformity with the results of Cáceres et al. [16].

Total carbohydrate content: The increase of carbohydrate content in modern chicken nuggets could be due to an increase of starch content 


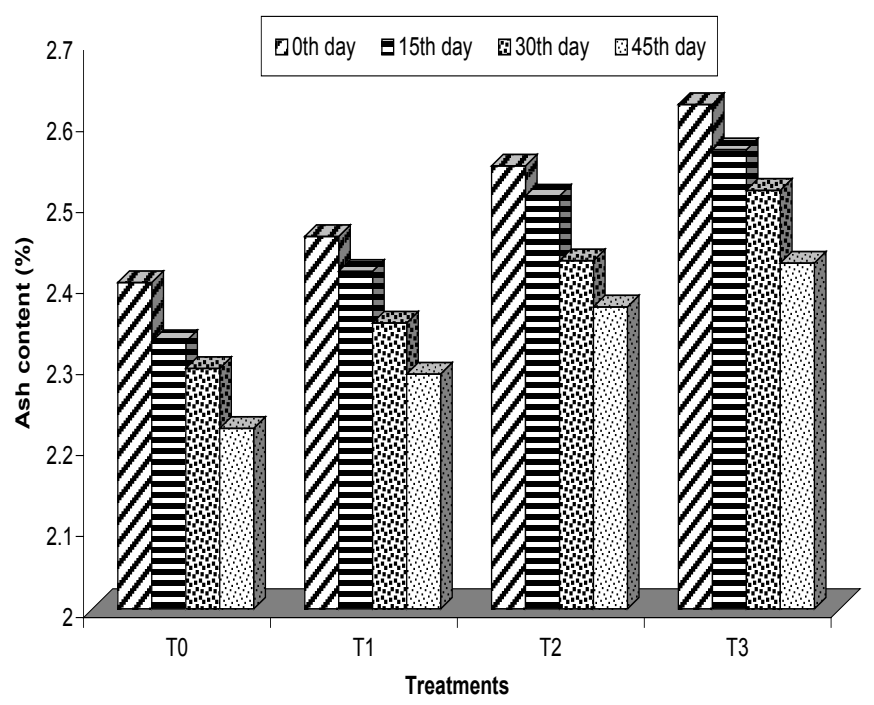

Figure 3: Ash content (\%) of low fat chicken nuggets packed in HDPE during 45 days of refrigerated storage.

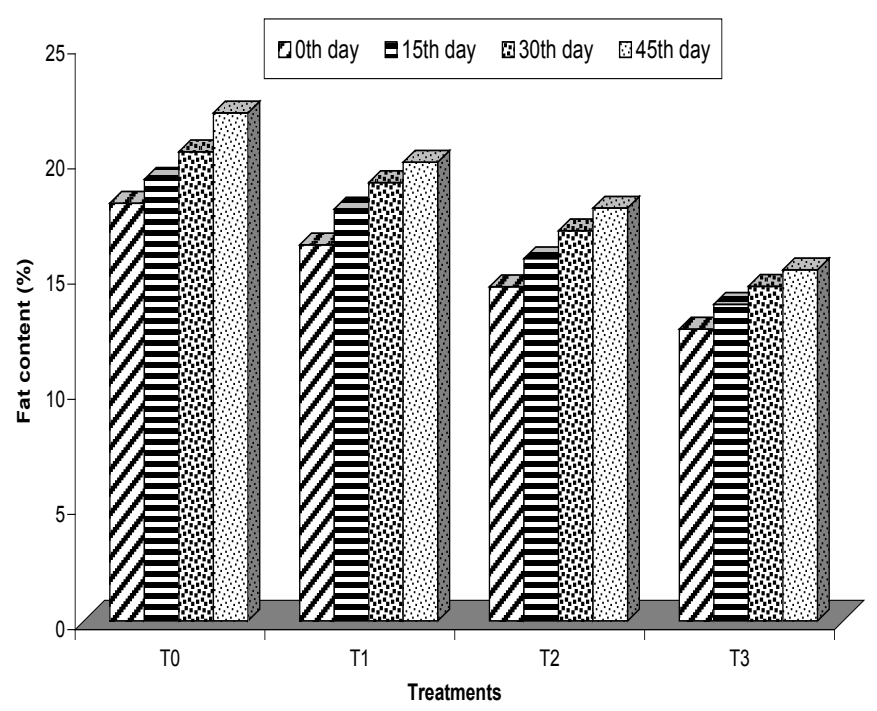

Figure 4: Fat content (\%) of low fat chicken nuggets packed in HDPE during 45 days of refrigerated storage.

(acts as extender) to substitute for raw meat in the manufacturing of chicken nuggets. The main reason behind this is the manufacturer plans to reduce processing cost to increase the marginal profit It has been observed that the initial value of carbohydrates in all the samples are $14.827 \%, 16.197 \%, 17.633 \%$, and $19.690 \%\left(\mathrm{~T}_{0}, \mathrm{~T}_{1}, \mathrm{~T}_{2}\right.$ and $\left.\mathrm{T}_{3}\right)$ and after the storage period of 45 days the carbohydrates content observed are $9.810 \%, 11.937 \%, 12.463 \%$ and $12.463 \%\left(\mathrm{~T}_{0}, \mathrm{~T}_{1}, \mathrm{~T}_{2}\right.$ and $\left.\mathrm{T}_{3}\right)$ (Figure 6). This variation is due to formulation of thio-barbutric acid (TBA) which digests the carbohydrate for their formulation.Similar results was also reported by Field [13].

\section{Yeast and mold count (C.F.U.) /g. or / $\mathrm{ml}$.}

Average Score for yeast and mould of Experimental low fat chicken nuggets: Table shows gram-ve (Gram negative bacteria) result, which means that strict hygienic practice was observed during it preparation (Table 1).
Average Presumptive coli form of low fat chicken nuggets: Table shows gram-ve (Gram negative bacteria) result, which means that strict hygienic practice was observed during it preparation (Table 2).

\section{Organoleptic analysis}

Evaluation of low fat chicken nuggets was done for color, appearance, flavor, taste, body and texture, overall acceptability using hedonic scale score and method (0-9 scores) (Figure 7). All the experiments were replicated thrice except the sensory evaluation which was replicated ten times and all the data were analyzed statistically to ascertain the significance. It has been observed that the initial value of all the samples are $\left(\mathrm{T}_{0}, \mathrm{~T}_{1}, \mathrm{~T}_{2}\right.$ and $\left.\mathrm{T}_{3}\right)$ and after the storage period of 45 days the colour and appearance, flavour and taste, body and texture and overall acceptability content observed are $\left(\mathrm{T}_{0}, \mathrm{~T}_{1}, \mathrm{~T}_{2}\right.$ and $\left.\mathrm{T}_{3}\right)$. Sensory evaluation showed significant reduction $(P<0.05)$ in overall acceptability scores of treatment products; however, scores were in the range of very good sensory attributes of the product were

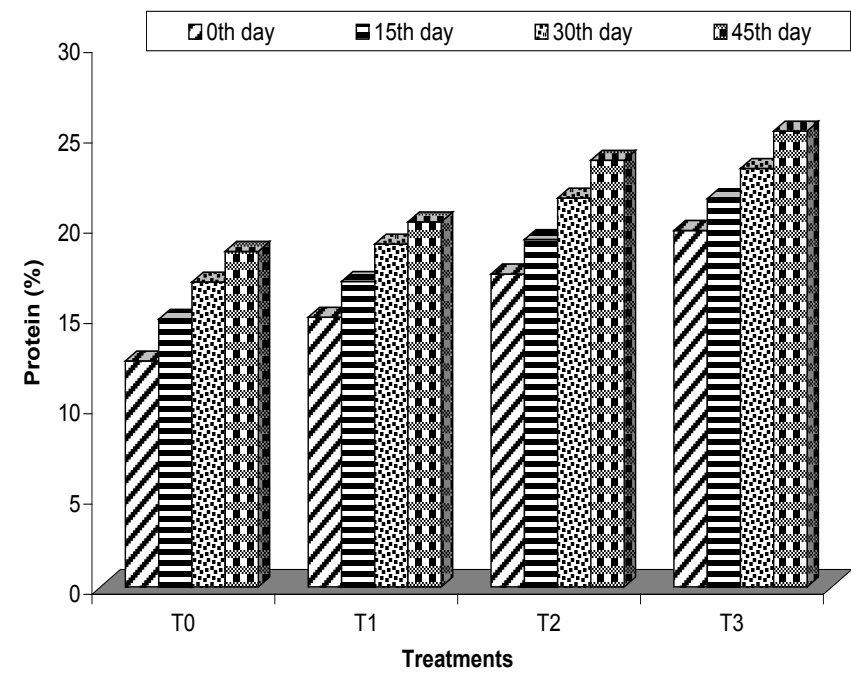

Figure 5: Protein (\%) of low fat chicken nuggets packed in HDPE during 45 days of refrigerated storage.

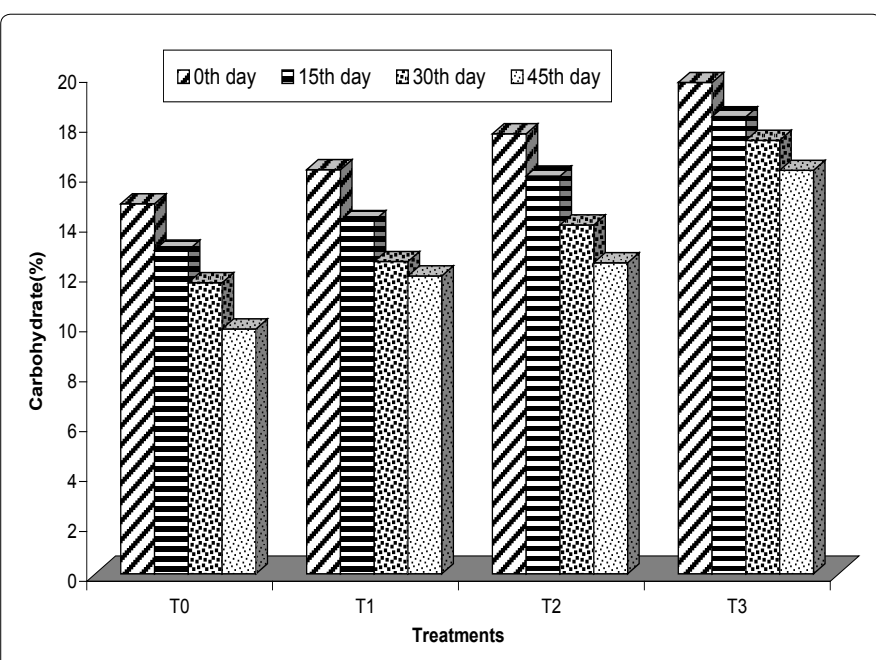

Figure 6: Total Carbohydrate content (\%) of low fat chicken nuggets packed in HDPE during 45 days of refrigerated storage. 
Citation: Singh AK, Sonkar C, Messih D (2014) Development and Physico-Chemical Evaluation of Low Fat Chicken Nuggets using Extenders. J Food Process Technol 5: 369. doi:10.4172/2157-7110.1000369

Page 5 of 5

\begin{tabular}{|c|c|c|c|c|}
\hline \multirow{2}{*}{ Repltications } & \multicolumn{4}{|c|}{ Treatment } \\
\cline { 2 - 5 } & $\mathbf{T}_{\mathbf{0}}$ & $\mathbf{T}_{1}$ & $\mathbf{T}_{\mathbf{2}}$ & $\mathbf{T}_{4}$ \\
\hline $\mathrm{R}_{1}$ & Negative & Negative & Negative & Negative \\
\hline $\mathrm{R}_{2}$ & Negative & Negative & Negative & Negative \\
\hline $\mathrm{R}_{3}$ & Negative & Negative & Negative & Negative \\
\hline
\end{tabular}

(G-ve = Gram negative bacteria)

Table 1: Average Score for yeast and mould of Experimental low fat chicken nuggets.

\begin{tabular}{|c|c|c|c|c|}
\hline \multirow{2}{*}{ Replications } & \multicolumn{4}{|c|}{ Treatment } \\
\cline { 2 - 5 } & $\mathbf{T}_{0}$ & $\mathbf{T}_{1}$ & $\mathbf{T}_{2}$ & $\mathbf{T}_{4}$ \\
\hline $\mathrm{R}_{1}$ & Negative & Negative & Negative & Negative \\
\hline $\mathrm{R}_{2}$ & Negative & Negative & Negative & Negative \\
\hline $\mathrm{R}_{3}$ & Negative & Negative & Negative & Negative \\
\hline
\end{tabular}

(G-ve = Gram negative bacteria)

Table 2: Average Presumptive coli form of low fat chicken nuggets.

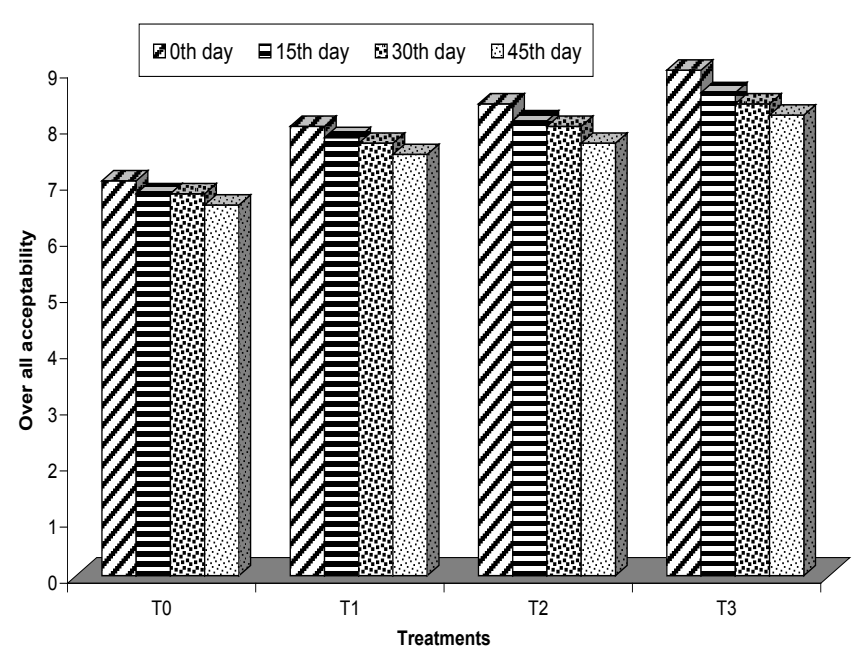

Figure 7: Over all acceptability of low fat chicken nuggets during 45 days of refrigerated storage.

not affected with salt replacement; however, inclusion of bottle gourd at higher levels decreased $(P<0.05)$ flavour and texture scores $[17,18]$. The comparable flavors scores of low fat - chicken nuggets at 7.00 and 8.20 chickpea flour and soya chunk with control production could be due to pronounced off flavour at higher levels of low fat chicken nuggets product as reported by Pandeya [19]. The difference in colour properties of chicken nuggets may be attributed to the effect of oil temperature and sample thickness during frying. The colour change phenomenon gets more intense at higher temperatures and smaller sample thickness [20].

\section{Conclusion}

Based on the analysis results, proximate composition, colour, textural properties and sensory evaluation tests, several batches of low fat chicken nuggets were significantly quite different. The differences in nuggets were mainly due to the type and amount of ingredients added and different formulation. The analysis results obtained in this study shows that manufacturers of low fat chicken nugget products in India produce with different formulations. Therefore, it should be reasonable to carry out a study to produce general guidelines for better quality low fat chicken nuggets.

\section{References}

1. Ray FK, Parrett NA, Van Stavern BD, Ockerman HW (1981) Effect of soy level and storage time on the quality characteristics of ground beef patties. J Food Sci 46: 1662-1664

2. Miles CW, Ziyad J, Bodwell CE, Steele PD (1984) True and apparent retention of nutrients in hamburger patties made from beef or beef extended with three different soy proteins. J Food Sci 49: 1167-1170.

3. McWatters KH (1977) Performance of defatted peanut, soybean and field pea meals as extenders in ground beef patties. J Food Sci 42: 1492-1495.

4. Torgersen H, Toledo RT (1977) Physical properties of protein preparations related to their functional characteristics in comminuted meat systems. J Food Sci 42: 1615- 1620.

5. Cross HR, Nichols JE (1979) Palatability of ground beef patties containing peanut meal, structured soy protein, and mechanically processed beef. Peanut Sci 6: 115-118.

6. McWatters KH, Heaton EK (1979) Quality characteristics of ground beef patties extended with moist-heated and unheated seed meals. JAOCS 56: 86A-90A.

7. Perkins D, Toledo RT (1982) Effect of heat treatment for trypsin inhibitor inactivation on physical and functional properties of peanut protein. J Food Sci 47: 917-923.

8. Prinyawiwatkul W, Beuchat LR, McWatters KH (1993a) Functional property changes in partially defatted peanut flour caused by fungal fermentation and heat treatment. J Food Sci 58: 1318-1323.

9. Prinyawiwatkul W, McWatters KH, Beuchat LR, Phillips RD (1997a) Functional characteristics of cowpea. (Vigna unguiculata) flour and starch as affected by soaking, boiling, and fungal fermentation before milling. Food Chern 58: 361 372.

10. Brown LM, Zayas JF (1990) Com germ protein flour as an extender in broiled beef patties. J Food Sci 55: 888-892.

11. Reitmeier CA, Prusa KJ (1991) Composition, cooking loss, color and compression of ground pork with dry- and wet-milled corn germ meals. J Food Sci 56: 216-219.

12. Prinyawiwatkul W, Beuchat LR, Phillips RD, Resurreccion AVA (1995) Modelling the effects of peanut flour, feed moisture content, and extrusion temperature on physical properties of an extruded snack product. Int $\mathrm{J}$ Food Sci Techrwl 30: 37-44.

13. Field RA (1976) Mechanically deboned red meat: properties, problems and utilization of mechanically deboned muscle tissue. Food Technology. 30(9): 38

14. Scheffe H (1958) Experiments with mixtures. JR Stat Soc B20: 344-360.

15. Giese J (1996) Fats, oils and fat replacers. Food Technology 50: 78-83.

16. Cáceres E1, García ML, Selgas MD (2006) Design of a new cooked meat sausage enriched with calcium. Meat Sci 73: 368-377.

17. Kumar V, Deo Sharma A, Rituparna B (2012) Quality characteristics of low-fat chicken nuggets: effect of common salt replacement and added bottle gourd (Lagenaria siceraria L.). Food Science and Technology Journal of the Science of Food and Agriculture 92: 1848-1854.

18. K Verma, Sharma BD, Rituparna B (2010) Effect of sodium chloride replacement and apple pulp inclusion on the physico-chemical, textural and sensory properties of low fat chicken nuggets. Food Science and Technology LWT - Food Science and Technology 43: 715-719.

19. Pandeya AC (1988) Soybean as economic proteinsonice Soybean processing and utilization in India, CIAE Bhopal.

20. Kadan RS, Bryant RJ, Pepperman AB (2003) Functional properties of extruded rice flours. J Food Sci 68: 1669-1672. 